\title{
Dr. Ben Agger: Colleague and Friend
}

\author{
Robert L. Bing III
}

\section{The Early Years}

This essay is a reflection of Dr. Ben Agger as a colleague and friend. I met Ben Agger when he was a candidate for the position of dean of the College of Liberal Arts at the University of Texas at Arlington. He was one of the brightest candidates in the selection pool; he was offered the position. I began a relationship with him immediately, as I was chair of the Department of Criminology and Criminal Justice. We worked together through good and bad times for the Department of Criminology and Criminal Justice. Ben advocated for my Department during some difficult times, when my unit was growing and the University was going through a period of entrenchment. In fact, I still have a memo written by then Dean Ben Agger articulating the needs of a unit with enormous growth potential; he helped argue for new faculty lines and increased funds for my department. In many ways, Ben was no non-sense in his approach to administration; he was data driven. Concomitantly, he was forward thinking as well. He recognized the potential of my discipline, even when faculty attrition was a problem. We had lost a faculty member to retirement and one to kidney cancer and another had left for placement in another unit. Ben challenged the university to help save the program. He also advocated for other academic units within the College. Ben was fair-minded in his approach to supervision and administration of all the units within the College. Of many attributes, he would make telephone calls or send cards with expressions of gratitude for service or accomplishment. One such card, dated, $10 / 26$ reads, “...many thanks for your continued professionalism and collegiality. I especially appreciate your effort to enhance faculty and student diversity. - ben" Please note use of small caps to spell his name, which was typical of Ben's style, demeanor and humility. Over the years, we became friends, a status that ranks higher than being a colleague.

\section{A Budding/Growing Friendship}

My relationship with Ben extended beyond the UT Arlington campus; we both had kids enrolled at the Montessori Academy (in Arlington). We shared the joys of parenting wonderful kids. We both recognized that there was more to life than the challenges, politics and contradictions of academic life. As a colleague and friend, I could sense Ben's keen interest in both of his kids. In many ways, I learned by listening to Ben talk with his kids. He had a knack for using humor and candor; he was the consummate disciplinarian, companion and friend for his kids. I want to believe that he influenced me in the raising of my daughter. Ben and I enjoyed countless trips to Six Flags, an amusement park in the entertainment section of Arlington, TX. We enjoyed rides on the roller coaster with our kids. The trip to Six Flags was such a ritual, we had season passes and season parking. The visits to the amusement park and Montessori sponsored field trips were sacred times with our children; we did not use the time to talk about politics, tenure, nor enrollment issues at UTA. As such, it was easy to be with Ben off the campus or at his home for a birthday party. It is not often that a colleague becomes a true friend. 


\section{A Confidante}

When his term as Dean and my tenure as chair ended, the relationship continued. My colleague Ben was supportive of my research and encouraged me to remain focused on it. We both agreed that no matter what happened, no one could take that away. Ironically, later in our careers at UTA, we were neighbors, with offices on the second floor of University Hall. Ben, a genius and true intellectual had become Director of the Center for Theory, within the Department of Sociology and Anthropology. He shared his ideas with me and invited me to the brown bags sponsored by the Center. I attended as many as I could. We talked more openly about politics and even university leadership, during this time period. It was easy to do, as we had both seen so much, including the successes and failures in leadership on the campus. If I had a concern and shared with Ben, it would remain confidential. This reality reflects character and the attributes of a colleague with a strong moral compass. My lament is that we never coauthored articles together on issues like social justice.

\section{Ben, The Intellectual}

Ben was a bright person; he was always aware of the shifts in politics at the national and international level. He valued all of the ideals of the academy, such as freedom of speech, scholarship and teaching. Through my lenses, Ben was the consummate instructor, there were always students around his office, motivated or enlightened by a classroom lecture. Concomitantly, Ben had the extraordinary gift of leadership, he continued to be actively involved as a leader within the department of sociology and anthropology. And in my opinion, he never retreated as many do, who have held prior positions of leadership and authority. As a colleague, Ben challenged you to be engaged and to overcome the landmines that exist in academe. I remember him talking about the importance of self-reflection and academic achievement. He influenced me to be more analytical about the politics of the world, including the politics of the academy.

\section{Conclusion}

In all, Ben was a true friend; he was relentless in his pursuit of scholarship, excellence and the truth. Thoughts of Ben reinforce our shared values that of all things, family and friends are fundamentally important. Like Ben, I pledged many years ago - to make a difference, to build bridges, to be reflective, to be inquisitive, to challenge students in the classroom, to leave a legacy and to champion the here and now. 